Article

\title{
Spirituality and Creativity in Coping, Their Association and Transformative Effect: A Qualitative Enquiry
}

\author{
Dagmar Anna S. Corry ${ }^{1, *}$, Anne P. Tracey ${ }^{2}$ and Christopher Alan Lewis ${ }^{1}$
}

1 Department of Psychology, Glyndŵr University, Plas Coch Campus, Mold Road, Wrexham LL11 2AW, Wales, UK; E-Mail: ca.lewis@glyndwr.ac.uk

2 School of Psychology, University of Ulster, Magee College, Northland Road, Londonderry BT48 7JL, UK; E-Mail: ap.tracey@ulster.ac.uk

* Author to whom correspondence should be addressed; E-Mail: d.corry@glyndwr.ac.uk; Tel.: +44-0-2881-658582.

Academic Editors: Arndt Büssing and René Hefti

Received: 27 January 2015 / Accepted: 8 April 2015 / Published: 17 April 2015

\begin{abstract}
While the beneficial effects on mental health of spirituality and creativity as separate entities have been well documented, little attention has been given to the interactive effect of the two constructs in coping. Recently, the theory of transformative coping and associated Transformative Coping Model have been developed and examined from both theoretical and quantitative perspectives. To extend this work, the present study critically examined the theory of transformative coping and associated Transformative Coping Model from a qualitative perspective. Ten interviews were conducted among Northern Irish and Irish artists, contemplative prayer group members, and mental health service users. Data were analysed using Interpretative Phenomenological Analysis. The results showed that the majority of participants had experienced stress and trauma, and have suffered mental ill-health as a consequence. Most defined themselves as both creative and spiritual, and resorted to a spiritual attitude along with creative expression in order to cope with traumatic events and ongoing stressful situations. Most participants believed that their creativity was rooted in their spirituality and that the application of both helped them to transform negative emotional states into positive ones. This, in turn, gave them increased resilience to and a different perspective of stressful events, which aided and improved their coping skills throughout the lifespan.
\end{abstract}


Keywords: creativity; spirituality; coping; transformative coping; stress; mental health; resilience; Interpretative Phenomenological Analysis (IPA)

\section{Introduction}

To facilitate the understanding and promotion of transformative coping, it is necessary that its components and their mutual association are explained. Eminent artists (e.g., [1,2]) and scientists (e.g., [3-5]) saw creativity and spirituality intrinsically linked in as much as creativity is understood as an aspect of spirituality. Tolstoy [2] and Kandinsky [1] believed that art was a means of emotional expression and communication, whereby the emotion is closely linked to the soul.

Recently, Corry, Lewis, and Mallett [6] presented a first introduction to the theory of transformative coping (TTC) which proposes the combined application of spirituality and creativity as a positive and pro-active coping strategy.

The TTC is based on the premise that both creativity and spirituality are aspects and expressions of the human spirit (e.g., [3,7]) and are thus connected (e.g., [1,2]). Coleman [3] and Jacobs [8] explained that creativity and spirituality mutually affect one another, and Bray [9] saw creative expression as an important step in the psycho-spiritual transformation of individuals.

Through the application of Interpretative Phenomenological Analysis ("IPA") [10] the present study was dedicated to qualitatively investigating how the phenomenon of transformative coping works for a sample of ten participants. The aim was to establish whether and to what extent individuals use their creativity as well as their spirituality in coping throughout their lifespan, how they are helped by resorting to them; and how important they are to them.

The research questions were:

(1) Are creativity and spirituality used in coping and if so, how are people helped by resorting to them?

(2) Are spiritual and creative coping used in conjunction? And, what is thus the lived experience of transformative coping?

(3) What does it mean to the participants to apply creative and spiritual coping and how important is it to them?

Thus, in seeking to establish what it means to the participants to be able to resort to their combined inner resources of creativity and spirituality in an effort to cope with psychological stress, this study applied the Transformative Coping Model ("TCM-R"; for the original model, see [6]) as a conceptual framework for the TTC.

\subsection{The Transformative Coping Model (TCM-R)}

\subsubsection{What is the TCM-R?}

Figure 1 illustrates the TCM-R - the original model was introduced by Corry, Lewis, and Mallett [6] — which is based on the premise that creativity and spirituality are intrinsically connected and related [1,2] as they are both expressions of the human spirit [3,7]. At the interface of 
this connection lies the opportunity for positive transformation and personal growth $[3,11]$. Creativity [12] and spirituality [13] are both a search for the sacred, with creativity also being a search for the self [10]. Both creativity [11] and spirituality [14] have transformative power and are a quest for meaning and unity [3].

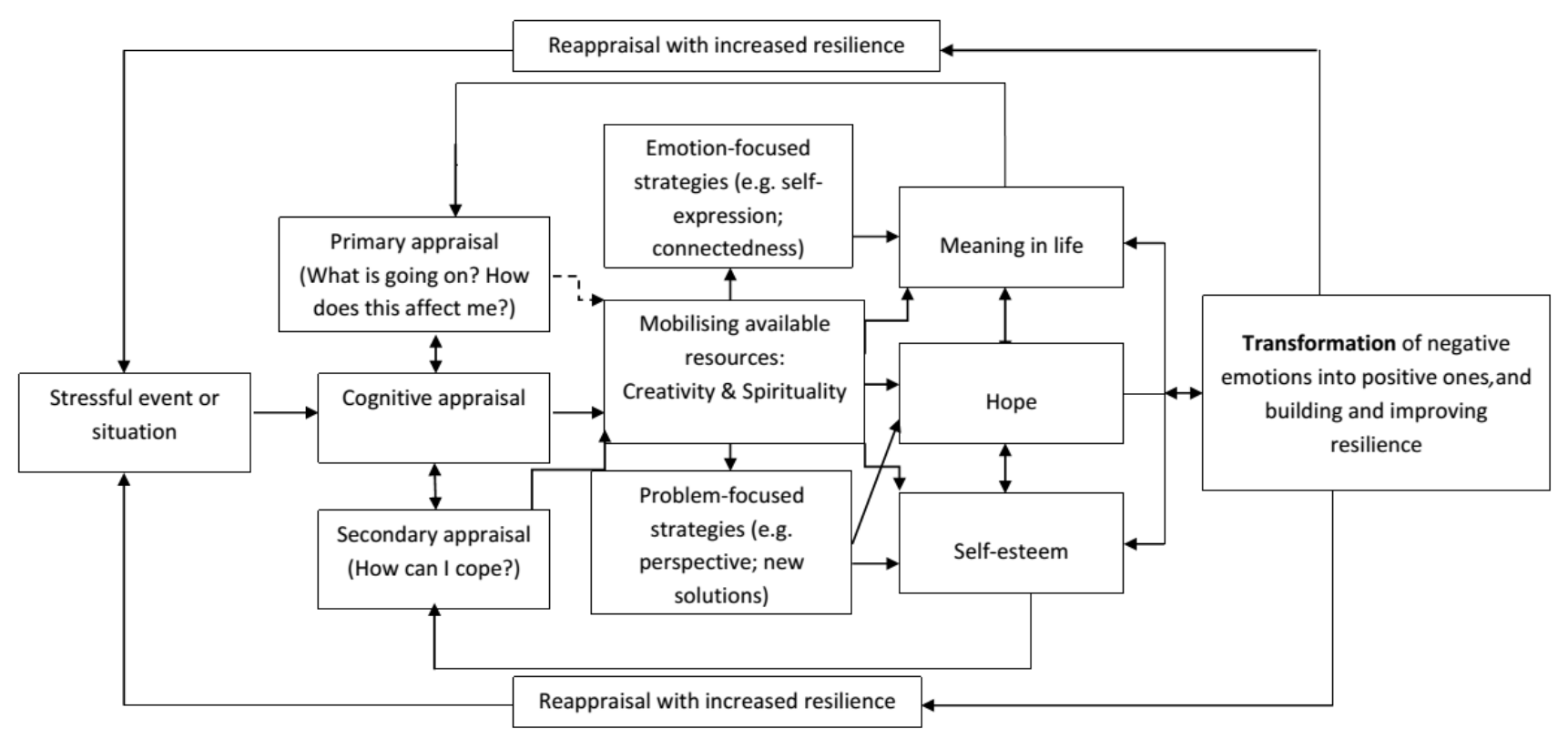

Figure 1. The revised transformative coping model ("TCM-R"; see [6] for the original model).

The TCM-R provides a new, efficient, accessible and universally applicable coping strategy. This model (see Figure 1) is rooted in Lazarus' [15] well-known Stress and Coping Model and links into Fredrickson's [16] broaden-and-build theory of positive emotions. Lazarus and Folkman's [17] Stress and Coping Model includes problem-focused-, and emotion-focused strategies. When encountering a stressful event, an individual will appraise it cognitively. During the primary appraisal process the individual evaluates whether a situation is a threat to well-being. It is the subjective appraisal of an event which turns it into a stress-encounter rather than the event in itself. Individuals' responses to a specific occurrence can differ substantially depending on its inherent significance to them, irrespective of the extent of the loss, hurt or problem. Lazarus and Folkman [17] differentiate between harm/loss, (where the damage has already been sustained), threat, (harms or losses are anticipated, permits anticipatory coping, involves negative emotions like fear, anxiety, and anger), and challenge appraisal (also calls for mobilisation of coping efforts, but is growth-oriented and involves positive emotions, like excitement and exhilaration). During the secondary appraisal process individuals evaluate which of their own resources they could resort to in the coping process.

Fredrickson's [16] theory describes how through the repeated cultivated experiencing of positive emotions people transform themselves and become more creative, more resilient, increase their personal resources and become more socially integrated and healthy individuals. This enables them to cope with and counteract negative emotions.

Building on these models, the TCM-R describes how during cognitive appraisal problems are evaluated often leading to negative emotions (e.g., anxiety, fear, anger, guilt, despair, hopelessness, etc.) but that through combining creativity and spirituality as a positive and pro-active, life-long coping strategy 
these negative emotions are transformed into positive ones (e.g., joy, love, gratitude, inspiration, serenity, interest, etc.), bringing with it an increased sense of meaning in life, hope, and self-esteem. As a result, negative emotions are transformed into positive ones and resilience is improved, which leaves the individual in a position to more positively (re-)appraise stressful current and future events. So, on the one hand, the TCM-R works very much on the principle of emotion management because: "The bottom-line message is that people should cultivate positive emotions in themselves, but also as a means to achieving psychological growth and improved psychological and physical well-being over time." ([16], p. 1367). On the other hand, the TCM-R affords perspective and fosters innovative solutions to problems. Transformative coping can play a vital role in the promotion and maintenance of mental health, prevention of mental ill-health, and aiding of recovery.

Fredrickson's [16] theory was influential to, and fits neatly with the TCM-R as it suggests the broadening of the thought-action repertoire (the range of thoughts and actions that come to mind when faced with a problem) and the building of enduring personal resources. "Through experiences of positive emotions, then, people transform themselves, becoming more creative, knowledgeable, resilient, socially integrated and healthy individuals" ([16], p. 1369). As Fredrickson [16] points out, negative emotions, when they are either extreme, not appropriate, or enduring, produce severe problems for individuals and, consequently, society. These difficulties include mental problems like phobias, anxiety disorders, aggression and violence, eating disorders and sexual dysfunction, as well as depression and suicide. They also result in a multitude of stress-related physical illnesses.

In contrast, positive affect is related to flexible and creative thinking, increased attention, open-mindedness and efficiency; it broadens cognition and increases resilience. Fredrickson [16] suggests in her "undo" hypothesis that positive emotions can correct the effects of lingering negative emotions. This is where the TCM-R links in, proposing the transformation from negative emotional states into positive ones through the combined application of creativity and spirituality in coping.

\subsubsection{How Does the TCM-R Work?}

The TCM-R suggests that, to begin with, a traumatic event or ongoing stressful situation is cognitively appraised. This appraisal consists firstly of the primary appraisal [17], which serves primarily as an evaluation of the problem or situation. This evaluation is followed by the secondary appraisal process, during which individuals establish which resources they have available in order to first, cope with or manage the emotional effect the problem has on them and second, find an effective solution to the problem. As a result of the secondary appraisal process, individuals mobilise their creative and spiritual resources and put them into practice.

This takes the form of becoming spiritually aware by connecting with self, others and the world around them, and in many cases, with God or a higher power. They focus on positive human values, inner peace and finding meaning and purpose in life. They actively seek a new perspective by considering that life has meaning beyond their immediate problematic circumstances. They become aware of the metaphysical and transcendent dimension in the world and within their relationships.

Subsequently, individuals can mobilise their creative resources and express themselves - that is their spiritual meaning finding and meaning making - in whichever form and through whichever medium suits them best (cooking, drawing, gardening, music, painting, sewing, woodwork, etc.). They 
find relief in being able to express their thoughts and emotions through a creative medium; it affords them a new perspective, and through fostering their imagination, it enables them to find innovative solutions to problems.

This combined application of their spiritual and creative resources allows individuals to find and maintain a sense of meaning and purpose in their lives, it gives them hope and self-esteem, all of which have been shown to contribute to mental health. For instance, hope has been implicated as a source of resilience (e.g., [18]), positive affect [19], described as a vital coping resource (e.g., [20]), and a key psychological strength [21]. Self-esteem has been shown to be an effective buffer against stress (e.g., [10,22]), implicated in coping with chronic illness [23], and to support well-being [1], positive affect in chronic disease patients [22] and mental health [24]. Meaning in life, in particular, has been strongly associated with coping and mental health [12,13,25-32].

Hope, self-esteem, and meaning-in-life impact positively on the cognitive appraisal process and the individual is able to reappraise the situation or event from a new perspective which changes the perception of the stressful event. As a result, negative affect is diminished. For example, Juth, Smyth, and Santuzzi [22] showed that self-esteem influences secondary appraisal, and Snyder [19] demonstrated the association between hope, self-esteem and meaning in life. As Lazarus [15] points out, it is the meaning attached to an occurrence that shapes a person's emotional and behavioural response.

Lazarus and Folkman ([17], p. 375) emphasise "To be effective, any stress management program must stimulate the person to appraise situations and/or cope with their demands in new ways." The TCM-R represents a conceptual framework for positive, proactive and effective coping across the lifespan. By applying the tenets of the model individuals become aware of their inherent positive resources. They are thereby enabled to help themselves as and when they need to and in a manner that suits them personally.

\section{Method}

The methodology employed for this study was Interpretative Phenomenological Analysis ("IPA") [33-35], a qualitative research approach which is widely used in contemporary British psychology [32] and which aims to explore individuals' perceptions of the lived experience of particular phenomena and what personal meaning their experiences have for them. A core principle of IPA [32] is that all description constitutes a form of interpretation. It does not involve "bracketing" of presuppositions as they are necessary in the meaning-making process of understanding and interpreting of the phenomena under investigation. As such, analyses produced by the researcher are always an interpretation of the participant's experience. Using an idiographic approach IPA involves intensive and detailed engagement with individual cases, with insights integrated at later stages of the research.

\subsection{Participants}

Following ethical approval from the University Ethics Committee, a purposive (i.e., criterion-based) sample of ten adult participants was recruited from three key groups in order to obtain a clear picture of the phenomenon of transformative coping, and to allow for greater transferability Three artists (in order to ensure inclusion of creative individuals) were recruited from Northern Ireland and the Republic of Ireland via the internet, along with three members of a contemplative prayer group (in an 
effort to ensure inclusion of spiritual individuals) in Northern Ireland via a priest as gatekeeper; and four members of a mental health support group (in order to ensure inclusion of individuals who have experienced mental health difficulties) in Northern Ireland via a member of staff as gatekeeper.

\subsection{Procedure}

Participants were contacted by the researcher and a suitable time and place for interview was agreed. No incentives were provided. All participants received a detailed participant brief and consent form prior to interview. They were informed that they may change their mind at any time and discontinue with the interview, and were supplied with a list of support organizations they could contact if they became distressed as a result of the interview. In order to ensure confidentiality and anonymity, no identifying information was made available. Identifiers assigned to participants in analysis and write-up consisted of random initials. The semi-structured interviews were recorded and transcribed verbatim. The transcripts were entered into NVivo-7 [36], a software package designed to afford analysis of qualitative data. The individual transcripts were analysed according to Smith, Jarman, and Osborn's [35] detailed method. The resulting theme structure is summarised in Figure 2.

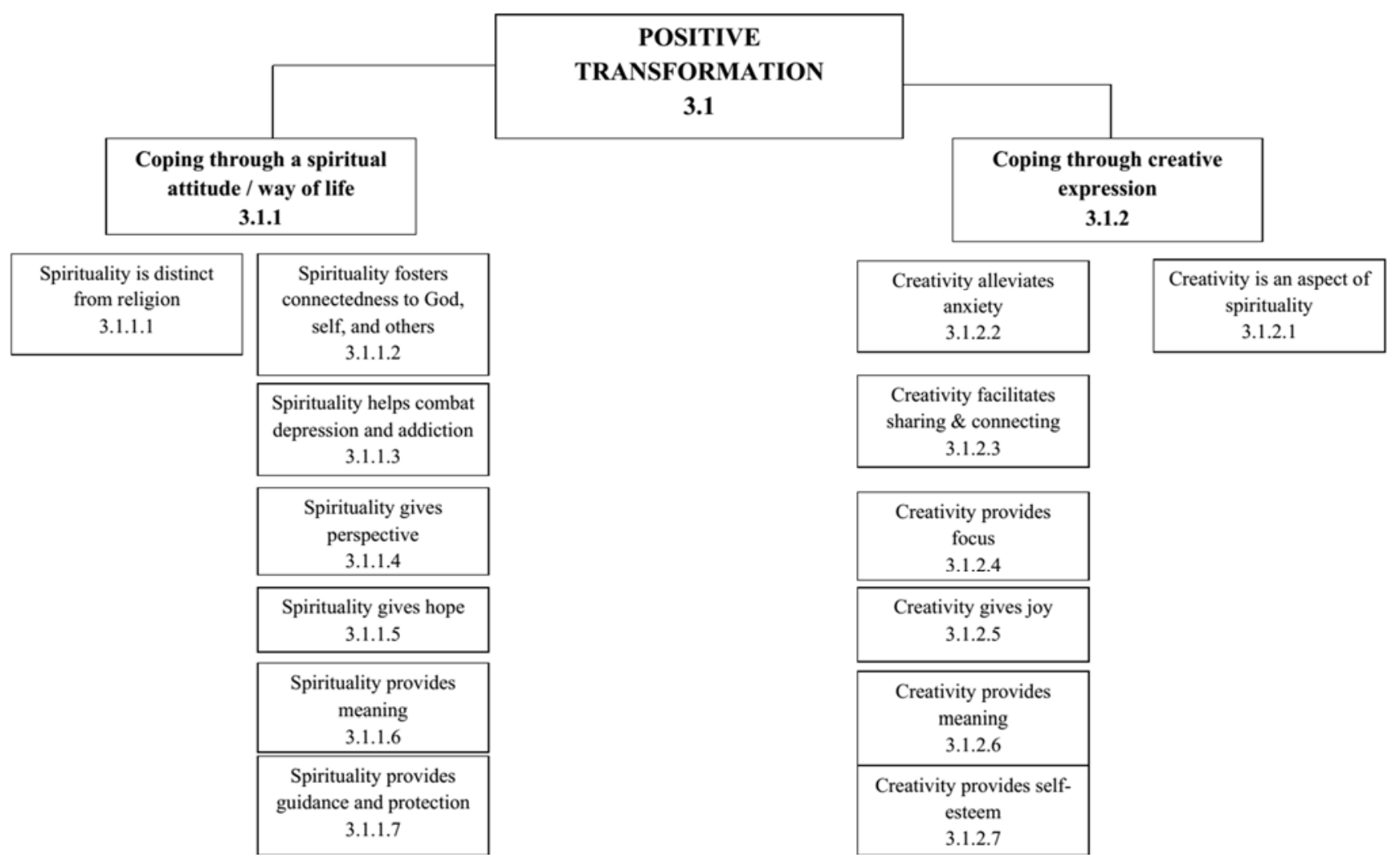

Figure 2. Theme structure for transformative coping.

Measures taken to ensure validity included participant triangulation, and the involvement of two further researchers to check the analysis and validate interpretations. To observe reflexivity the lead researcher (DASC) has examined the potential effects of her own beliefs, knowledge, and experiences of transformative coping on the current research. She acknowledged and retained an awareness of potential biases throughout the study, focusing on the participants' unique experience in a conscious 
effort to take an idiographic approach. Such biases include the researcher's knowledge of theoretical and empirical accounts of a positive association between creativity and spirituality, along with their salutogenic effect on wellbeing. The researcher also has personal experience of the beneficial effects of transformative coping.

\subsection{Topic Guides}

In order to ensure the richest data possible, semi-structured topic guides were used as a framework, which allowed the interviewees ample opportunity to elaborate as much or as little as they felt comfortable with and tell their story in their own words Typical questions, which were followed up with appropriate prompts, where applicable, were: "Do you resort to your spirituality in times of trouble?Could you give me an example of this?", and: "Can you remember an instance where resorting to your craft has helped you overcome a problem?" The topic guides were constructed specifically with the view to ascertain whether the interviewees considered themselves spiritual and/or creative; whether they applied their creativity and spirituality in coping; what this meant to them, and how important it was to them. The interview guide can be requested from the corresponding author.

In line with recommendations by Smith and Osborn [34] a conscious effort was made to conduct every interview with the utmost respect for the participant and their unique story. This involved intense listening and observation, including "hearing" and noticing what was not said. Participants were not rushed through the questions but care was taken to allow them to take the lead within reasonable reach of the topic. Any information obtained was freely given by the participants rather than coerced from them.

\section{Findings}

This section presents and interprets interview excerpts illustrating the super-ordinate themes and their respective sub-themes as they emerged from IPA [35] and as summarised in the theme structure in Figure 2. Table 1 provides a brief summary of demographic details and findings. The gender distribution was even with five male and five female participants. Ages ranged from 29 to 70; six participants were single, three were married, and one was divorced.

Creativity (eight participants) and spirituality (seven participants) were used in coping, with six participants applying a combination of both capacities as a coping strategy. Two participants did not see themselves as creative, while three said they were not spiritual, with one of them being neither creative nor spiritual. The following quotes and interpretations illustrate the lived experience of transformative coping and demonstrate what it means to the participants to apply creative and spiritual coping. All initials used to denote particular participants are fictional. 
Table 1. Participants' commonalities and differences.

\begin{tabular}{|c|c|c|c|c|c|c|c|c|c|c|}
\hline & Artist & Artist & Artist & $\begin{array}{l}\text { Mental Health } \\
\text { Group Member }\end{array}$ & $\begin{array}{l}\text { Mental Health } \\
\text { Group Member }\end{array}$ & $\begin{array}{l}\text { Mental Health } \\
\text { Group Member }\end{array}$ & $\begin{array}{l}\text { Mental Health } \\
\text { Group Member }\end{array}$ & $\begin{array}{c}\text { Prayer Group } \\
\text { Member }\end{array}$ & $\begin{array}{c}\text { Prayer Group } \\
\text { Member }\end{array}$ & $\begin{array}{c}\text { Prayer Group } \\
\text { Member }\end{array}$ \\
\hline ID & $\mathrm{JB}$ & LM & $\mathrm{RN}$ & $\mathrm{HN}$ & LO & $\mathrm{SC}$ & PT & KS & $\mathrm{TC}$ & MR \\
\hline Gender & Male & Female & Female & Male & Male & Male & Female & Female & Male & Female \\
\hline Nationality & $\begin{array}{l}\text { Northern } \\
\text { Ireland }\end{array}$ & $\begin{array}{l}\text { Republic of } \\
\text { Ireland }\end{array}$ & $\begin{array}{l}\text { Republic of } \\
\text { Ireland }\end{array}$ & Northern Ireland & Northern Ireland & Northern Ireland & Northern Ireland & Northern Ireland & $\begin{array}{l}\text { Northern } \\
\text { Ireland }\end{array}$ & $\begin{array}{l}\text { Northern } \\
\text { Ireland }\end{array}$ \\
\hline $\begin{array}{c}\text { Marital } \\
\text { status }\end{array}$ & Single & Married & Divorced & Single & Single & Single & Single & Married & Married & Single \\
\hline Age & 29 & 54 & 57 & 37 & 52 & 41 & 44 & 55 & 70 & 48 \\
\hline Religion & Catholic & Catholic & Catholic & Catholic & Catholic & No denomination & Catholic & Catholic & Catholic & Catholic \\
\hline $\begin{array}{c}\text { Physical } \\
\text { illness }\end{array}$ & $\begin{array}{l}\text { None } \\
\text { reported }\end{array}$ & None reported & None reported & None reported & $\begin{array}{l}\text { Stomach } \\
\text { problems }\end{array}$ & None reported & None reported & $\begin{array}{c}\text { Obesity; Suspected } \\
\text { heart attack }\end{array}$ & Hernia & none \\
\hline $\begin{array}{c}\text { Mental } \\
\text { health } \\
\text { problem }\end{array}$ & Anxiety & $\begin{array}{l}\text { None reported } \\
\text { but anxiety } \\
\text { transpired }\end{array}$ & $\begin{array}{c}\text { None reported } \\
\text { but anxiety } \\
\text { transpired }\end{array}$ & $\begin{array}{l}\text { Depression and } \\
\text { PTSD }\end{array}$ & $\begin{array}{l}\text { Bipolar disorder; } \\
\text { Suicidal ideation }\end{array}$ & $\begin{array}{l}\text { Schizophrenia; } \\
\text { Anxiety and fear } \\
\text { are issues; } \\
\text { Alcoholism }\end{array}$ & $\begin{array}{c}\text { Paranoid } \\
\text { schizophrenia; } \\
\text { Anxiety is an issue }\end{array}$ & $\begin{array}{c}\text { Depression, } \\
\text { Addiction; Eating } \\
\text { disorder; Suicidal } \\
\text { ideation }\end{array}$ & None reported & $\begin{array}{c}\text { Depression and } \\
\text { anxiety }\end{array}$ \\
\hline $\begin{array}{l}\text { Trauma or } \\
\text { stressful } \\
\text { situation(s) }\end{array}$ & $\begin{array}{c}\text { Adopted. Ran } \\
\text { away from } \\
\text { home at } 16 \\
\text { (came back) }\end{array}$ & $\begin{array}{c}\text { Alludes to } \\
\text { difficult things } \\
\text { having } \\
\text { happened. }\end{array}$ & $\begin{array}{l}\text { "Troubled } \\
\text { childhood"; } \\
\text { Divorce }\end{array}$ & $\begin{array}{l}\text { Mother died } \\
\text { aged } 63 \text { of } \\
\text { motor-neuron } \\
\text { disease }\end{array}$ & Not known. & Lost job & Not known. & $\begin{array}{l}\text { Abuse; Death of a } \\
\text { child }\end{array}$ & $\begin{array}{l}\text { Allusions to } \\
\text { marital strife }\end{array}$ & $\begin{array}{l}\text { Death of } \\
\text { nephew and } \\
\text { sister }\end{array}$ \\
\hline Creative & Sculpture & Painting & $\begin{array}{l}\text { Singing; } \\
\text { Creative } \\
\text { writing }\end{array}$ & $\begin{array}{c}\text { Not actively but } \\
\text { appreciates } \\
\text { creativity }\end{array}$ & Creative writing & Creative writing & $\begin{array}{c}\text { Painting; Creative } \\
\text { writing }\end{array}$ & $\begin{array}{l}\text { Creative writing; } \\
\text { Flower-arranging, } \\
\text { singing/song-writing }\end{array}$ & $\begin{array}{l}\text { Says no; yet } \\
\text { proceeds to } \\
\text { recite poetry }\end{array}$ & $\begin{array}{c}\text { Flower- } \\
\text { arranging; } \\
\text { Interior } \\
\text { decorating }\end{array}$ \\
\hline Spiritual & $\begin{array}{l}\text { Yes, but not } \\
\text { religious. } \\
\text { Eastern } \\
\text { philosophy }\end{array}$ & $\begin{array}{c}\text { Says no, yet } \\
\text { demonstrates } \\
\text { spiritual } \\
\text { values }\end{array}$ & $\begin{array}{c}\text { Silent prayer; } \\
\text { Contemplative } \\
\text { prayer }\end{array}$ & $\begin{array}{l}\text { No: Paedophilia } \\
\text { among clergy; } \\
\text { Mother's death; } \\
\text { Division in NI }\end{array}$ & $\begin{array}{l}\text { Yes, but not } \\
\text { religious. The } \\
\text { "Troubles" in NI }\end{array}$ & Meditation & No & $\begin{array}{l}\text { Contemplative } \\
\text { prayer, reflection }\end{array}$ & $\begin{array}{c}\text { Contemplative } \\
\text { prayer, } \\
\text { reflection }\end{array}$ & $\begin{array}{c}\text { Contemplative } \\
\text { prayer; Silent } \\
\text { prayer }\end{array}$ \\
\hline
\end{tabular}




\subsection{Positive Transformation}

The superordinate theme established was that of positive transformation, with constituent themes being "Creative expression" and "Spiritual attitude/way of life", as well as the "Creativity is an aspect of spirituality". The theme of transformation was inherent in each main-, and subtheme. In other words, the application or attainment of the concepts which comprise the themes (i.e., focus, connecting to God, self or others, perspective, etc.) each brought about a positive transformation within the interviewee and, consequently, transformed their lives, making them more resilient, and better able to cope.

JB's quote regarding the application of wool in his art refers to the comforting, soothing, and transformative effect this has on him. He talks about his environment of political and religious conflict and links this statement directly to the material he uses in his art. He feels that the negative emotions that were evoked in him as a result of the conflict surrounding him, are eradicated and transformed into positive ones.

I'm from Northern Ireland and from the conflict that was here I would see that as a healing. In a way it's quite healing and therapeutic and very gentle. It has a transformative quality whenever you put it around hard, tough and rough surfaces so it has that transformative effect. (JB).

PT, who had lost a nephew in a tragic car accident, had to deal with her own grief while supporting her grieving sister, and mother of the young man. Together they resorted to refurbishing caravans as a way of coping with their sadness and despair. PT believes that this shared activity changed how they felt. It made them feel better: it transformed their outlook on the situation. "We done all that and it just changed things around and brought a bit of life and a bit of hope and maybe helped." (PT).

LM, who declared that her worst nightmare would be to have nothing to work with creatively, made a very profound statement when she said: "Life is change and an artist's work has to be about change. The nature of art is to push forward." (LM).

LM's quote captures the thinking behind, and the purpose of, transformative coping very well. Change, or transformation, is an intrinsic and fundamental part of life. Every change requires that we adapt to it. The more skillful people are in adapting, the better they cope. Tools that assist in this adaptive process are highly beneficial, and what LM is indicating here is that art is supremely suitable for supporting transformation.

\subsubsection{Coping through a Spiritual "Attitude" or "Way of Life"}

JB's quote captures the main theme of "spiritual attitude" very well. By taking a positive outlook on life in general, and towards oneself and other people in particular, a conscious choice can be made to view matters in a different light. Instead of focusing on negatives, a conscious and ongoing effort can be made to embrace any situation one finds oneself in and look for the good in it. Rather than perceiving oneself as terribly put upon, the same situation can be regarded as a challenge and thus take on different meaning.

[It's about] increasing your base level of happiness and about dealing with issues, even the people that are difficult to get along with, because you get that in every situation. That they 
are actually a special gift that help you practice patience and tolerance. If you were always around people you got along with you would never actually be able to develop as a human being. So it teaches you a different perspective, to look at situations from a different point of view. People that represent challenges, you can see them as a gift. (JB).

Spirituality, as a subjective construct, means different things to different people. This view has found support in this study as will become evident throughout this section. For example, for JB, spirituality was about human connections. He shared this personal meaning mostly with participants $\mathrm{HN}$ and LO. A further quote from JB demonstrates this very well, as he talks about the importance of making a positive contribution to peaceful relationships in one's immediate environment through practicing and applying desirable human qualities.

I think it's in a very, very small part that you want to contribute to humanity, just in the little environment that you are in, that you are doing something positive towards compassion and kindness, and practice patience, tolerance and forgiveness, that would bring a sense of peace and harmony to whatever situation you are in. To try and bring that to dissolve where there are tensions and bring peace and when I say that I am not talking on about some huge global scale, I just mean the environment that you are in. (JB).

JB's sentiments are echoed in LO's quotation, where a spiritual person is also interpreted as someone who takes a benevolent attitude towards others. In addition, LO defines a spiritual person as someone who's meaning in life is not oriented towards the material.

It's I think somebody that cares, cares about his fellow human beings, cares not to harm, particularly in terms of language and as well as physical, consideration and somebody who - it's very hard to do in this world — is not money-orientated. (LO).

\subsubsection{Spirituality is Distinct from Religion}

Despite the fact that there was no question on the interview guide with regard to religiosity, four participants made a distinction between religion and spirituality. One of them was MR, who was herself both spiritual and religious but was aware of a distinction between the two: "You know, there are people who could be spiritual but they might never go to mass or practice religion." (MR).

Three participants felt strongly about this distinction, declaring themselves to be spiritual only. LO implicated the religious conflict in Northern Ireland in his decision to abandon religion in favour of spirituality.

The troubles had something to do with it as well, I would have rejected all types of organised religion and start thinking for myself but I would have still believed in God and that sort of thing. (LO).

LO, who had had a traditional Irish Catholic upbringing, probably wanted to distance himself from the religious element of the political conflict in Northern Ireland, when he moved to England in order to attend college in his twenties. He made it very clear where he stood: "I would never describe myself as religious, I prefer the word spiritual." (LO). 
This theme is important because it highlights the importance of spirituality to the participants above and beyond organised religion. As such it once more underlines the intrinsic personal nature of spirituality. RN's quotation captures this aspect very well: "So that was the spiritual side, that was quite big and has accompanied my life rather than the religious, I had my own rules." (RN).

The associated excerpt illustrates perhaps why RN felt more drawn to spirituality than to religion. It seems an important aspect that could, again, be said to be related to meaning. Since RN felt excluded from her religion on the basis of her gender, this would have impacted profoundly on how significant religion was to her. As it was, it caused her to turn away from it and concentrate on her individual spirituality. "I was kind of rejecting the Romanised side of things and felt excluded really as a woman whereas in our own Celtic spirituality there are Goddesses, not Gods.” (RN).

Lastly, JB's sense of spirituality appears to have jarred with his religious background:

I have chosen my own path. My upbringing would have been from a Roman Catholic upbringing, but I felt that was, it just did not work for me. From what I consider spiritual, I didn't get a sense of the spiritual. (JB).

As a result, he distanced himself from religion and chose to live by his own definition of spirituality: "I mean I use the word spirituality here as opposed to religion because I am not religious." (JB).

\subsubsection{Spirituality Fosters Connectedness to God, Self, and Others}

Meditation and prayer were used by the interviewees as a means to connect with themselves or God. $\mathrm{SC}$, for example, not only had made prayer a daily item on his agenda as part of his spiritual journey to improved mental health: "I would pray in the morning, I pray every morning", but also resorted to mediation when he felt particularly unwell: "Yeah. I meditate whenever I'm bad, I would meditate." (SC).

In difficult times, LO sought quiet time alone in order to reflect: "I would pray more. I would go into churches for some peace and quiet, to sort myself out and try to get a resolution to my troubles." (LO).

He shared this approach to dealing with difficulties with $\mathrm{RN}$, who also resorted to quiet meditation in order to find answers: "If I am in a dilemma, then I would just go into that space, light a candle and just sit there, and, you know, listen." (RN).

The subtheme of "connecting through meditation and prayer" somewhat overlaps with that of "guidance" in that, in both themes, the interviewees looked for direction either from within themselves or from a higher power, and possibly both, as MR's quote shows:

It would be in silent prayer...I wouldn't pray like Rosaries and stuff. I go to church and Holy Communion but my main thing would be to spend time alone with God. Just time alone basically, trying to cope with things. But I definitely would resort to it a lot. (MR).

MR recounted how, after her nephew's untimely death, she and her sister derived a deep sense of support from regular contemplative prayer meetings and so were able to maintain a reasonable level of good mental health during the grieving period that followed: 
But we had already been going to the meetings with Fr. B. for years. Only for that I think, otherwise I don't know how we would have survived it, both of us. Ehm [sic], that was the only thing that kept us going through that black time. (MR).

Like SC, KS's spiritual way of life was guided by daily prayer and a request for direction and guidance in her daily thoughts, words and actions concerning herself as well as others:

I get on my knees every morning and I ask God or my higher power "Please God direct my day today, guide and protect me, help me with my abstinence around my food, guide my every thought, word and deed today, come into my very being and speak, use me as an instrument and speak your message to other people, your love to other people." (KS).

\subsubsection{Connectedness to God: Positive God Image}

It became evident during the interviews that those participants who considered themselves to be spiritual, had a positive image of God. SC, for example, saw God as a caring, understanding and forgiving power, who stood by him even during those times of his life which he was not proud of: "I mean I don't believe God ever really left me, even when I was a rogue, like." (SC).

$\mathrm{RN}$ developed a strong and very close relationship to God from very early on in her life. He is ever present in her life and she regularly connects with him through meditation. "Very early on I began to regard this transcendence or this God as my very best friend." (RN).

MR, who tragically lost two close family members within a short space of time, has found solace in contemplative prayer and believes that turning to God was her salvation: "I knew I couldn't survive without God. Without that help in me I couldn't have gone through it." (MR).

\subsubsection{Connectedness to Self: Increased Self-Awareness}

A spiritual way of life enabled the interviewees to become aware of their own weaknesses. As SC becomes more self-aware he learns to forgive himself which dispels his feelings of guilt and shame:

The best thing for me is that I can admit my faults, I can be honest and admit my faults and anything I done bad, I persevere and take it on the chin until its gone, until I'm more liberated all the bad things I done. (SC).

Having connected with herself at a deep level KS has learned to accept herself wholeheartedly, with all her strengths and weaknesses, and has achieved a high level of self-awareness.

I am still only a child, I make mistakes, I do know the difference. I have boundaries in my life today that I never had before, I have compassion and love and I do get angry. I am still a child, I get angry. I realise that sometimes other people's actions towards me actually stir up old behaviours but today I am aware of that. (KS).

On the other hand, HN did not seem to be in touch with himself and did not appear to know where he belonged. His own words were "I feel like I'm lost." He did not see himself as spiritual or religious and appeared to regard them as identical concepts. He had distanced himself from organised religion after the recent revelations of paedophilia within the Catholic Church, and after he lost his mother to motor-neuron disease at a relatively young age. 
I couldn't tell, some people could say to you, well, I'm a Christian, or I'm a Humanist or I'm this or I'm that, but I don't feel as if I have a sort of clear focus where I wanna [sic] go or who I wanna [sic] be, you know. (HN).

\subsubsection{Connectedness to Others: Positive Relations}

HN's understanding of a spiritual way of life centred on respectful relationships with his fellow human beings. For him, spirituality meant mutual respect, which is of course, a tremendously important aspect of human relations and so a vital component of a spiritual outlook in life:

Ehm [sic], I think basically it's a sort of understanding towards people and if you listen to people and try to understand them and try and not belittle people and treat them as an equal ...Just treat people the way you want to be treated. Treat people with respect. (HN).

TC endeavoured to apply his spiritual values in daily life in his relationships with others. His quotation is an excellent example of applied spirituality, where transforming something potentially destructive into something constructive is key.

I'm thinking of this morning...with my wife and, frequently the conversations we have are difficult and I would go into just prayerful mode and that and just asking God to give me the wisdom and guidance to derive something constructive out of this. (TC).

Asked how his spirituality manifests itself, LO referred to his efforts of actively supporting others. "I would seek to help people, advising them or helping them, you know." (LO).

\subsubsection{Spirituality Helps Combat Depression and Addiction}

Spirituality was described by the interviewees as a crucial factor in combating addiction and depression. SC, for example, who suffered from severe alcoholism, gives witness to that when he recalls how joining the spiritual program of Alcoholics Anonymous helped him overcome his alcohol addiction:

It helped my drink problem. It helped my alcohol problems...I had to make a decision, because the drink would have killed me or something or I could have got locked up. I would have been in a rubber room, you know. (SC)

KS described how her spiritual beliefs helped her in finally beating her food addiction and losing half her body weight, thus overcoming obesity: "So that would be my, I have come from a person of 22 stone weight today to a person of 10 stone, $12 \frac{1 / 2}{\mathrm{lb}}$ by the grace of God and a higher power. I am a miracle." (KS).

LO had suffered from suicidal ideation on a number of occasions throughout his life. In the following excerpt he makes reference to his belief that hope to carry on came from his own spiritual core:

Well, yeah, like I've had my bad times, obviously with bipolar, I've had serious severe depression and a couple of times I've been suicidal...But there's always a spiritual core that sort of holds you back and if you hadn't that you would do it. (LO).

Lastly, here is another excerpt describing how KS's spirituality, which expressed itself in prayer, has prevented her from committing suicide which she describes as a miracle: "That was a miracle that I 
was brought away from the suicide that was an instant miracle." LO and KS were the two participants in the study who had contemplated suicide in the past and both of them reported that it was their spirituality which stopped them from carrying out their intentions.

There was one stage where I was so, so distraught that I was on my knees, thinking about how I would commit suicide. I really didn't want to live and I had been conjuring up ways of how I commit suicide so that nobody would know. In the midst of all that I started to say the Hail Mary and just begged the mother of God, the mother of our Lord Jesus, to come and help me, ah, I went to my bed and I was in a really, really distraught, really distraught state and I went to sleep, I don't know how I done it, because normally I would have just been running tapes in my head and my tapes were very vivid films. And I went to sleep and I wakened in the morning with a calm that I hadn't known in a number of weeks, days, months. (KS).

\subsubsection{Spirituality Gives Perspective}

"Perspective" was one of the subthemes that the interviewees appeared to derive from both spiritual- as well as from creative coping, along with "connecting" and "increasing self-awareness": "It definitely helps you with the bigger picture, I think." (RM).

TC gave a splendid account of how he achieves perspective on things through consciously choosing to change his outlook on them and how he is thus able to transform his experiences of the daily grind from something stressful into something enjoyable and worthwhile:

Reaching out and embracing these things as an essential part of your mission, your vocation, your story in life. The wee book of St Peter would have a few of those terms if not more. It would be down there as part and partial of life and when you embrace it in that way it actually, you know, threatens the concept of hassle and enables you to live in the present and to embrace these things and to elevate them onto a higher plain if you like and in that way would it help me to cope with some of the daily hassles. (TC).

TC considered spirituality to be "part of my negotiation, my truth" (TC). I believe that it was his intensely spiritual outlook on life combined with, possibly, the fact that he was the oldest interviewee, which accounted for him having achieved the highest level of acumen of them all. His next quote, again, demonstrated his efforts to arrive at a positive perspective on life and maintain it:

Darkness isn't always maybe the enemy. It seems but an opportunity to push through to a new reality, to a new world or whatever, you know that type of possibility of coping with great, great difficulty. (TC).

Lastly, and importantly, TC emphasises the importance of the positive human virtue of gratitude. What he is saying is that rather than focusing on the negatives in life, by choosing to be grateful for the positives, the perspective changes, and life is transformed: "And then, to allow the attitude of gratitude ...and in that way negotiate the hassle and minimise the hassle and contextualise the hassle and making it a lot easier from that point." (TC). 
LO's quote demonstrates the importance of perspective obtained through a spiritual outlook, as it has prevented him from committing suicide:

There's always somebody worse in the world, African child, starving, so there's always something at the back of me. If you haven't got that spiritual conscience, you would take the easy option and take your own life, you know. (LO).

\subsubsection{Spirituality Gives Hope}

LO derived hope from his spirituality through his belief in a higher power and a higher purpose in life. In light of this he was able to change his perspective on his difficulties and contextualise them within a larger scheme of things, thereby making them seem less overpowering and more meaningful: “As I say, it gives you hope. To know that there's somebody up there looking after you. He's putting you through these challenges for a purpose." (LO).

LO's quote illustrates how his own spirituality prevented him from committing suicide. Importantly, he said that it was solely his spiritual core which stopped him from carrying out the act:

Well, yeah, like I've had my bad times, obviously with bipolar, I've had serious severe depression and a couple of times I've been suicidal. But there's always been a sort of inner voice, a spiritual one, sort of saying, things will get better, this is only temporary, you know. (LO).

MR had made notes on her interview schedule, one of which, with regard to the question as to how spirituality helps her with life's difficulties, read: "Gives me hope to keep going". This theme of hope enabling her to keep going in dark and difficult times is revisited during the interview when she refers to the contemplative prayer meetings she and her sister regularly attended after her nephew's demise: "Ehm [sic], that was the only thing that kept us going through that black time." (MR).

\subsubsection{Spirituality Provides Meaning}

Spirituality held great significance for the participants. Some identified entirely with it as in RN's case: "It's my essence, I think." RN had a very spiritual outlook on life, a strong connection with a well-meaning and protective God, and resorted to meditation and reflection on a regular basis.

Others, too, made it very clear, how much spirituality meant to them. KS, for example, who made time for spiritual reflection every morning and whose personal development and self-awareness was greatly guided and advanced through her spiritual attitude, said: "So, I could not live my life today without a spiritual way of being." (KS).

Equally, MR, who attends regular contemplative prayer meetings and who has found great solace, comfort and hope in spirituality after the loss of her nephew and sister, sees spirituality as an intrinsic part of her life. As such, it is of great significance to her: "Well, it's part of my life now and I wouldn't want to do without it basically." (MR).

Her sentiments are shared by TC, who describes spirituality as part of "his truth", a phrase close in meaning to RN's "my essence". "No, no. It would be part of my negotiation, my truth." (TC)

$\mathrm{JB}$, who declared that spirituality is more important to him than creativity and that spirituality flows through his art, expresses what spirituality means to him in the following quote. He is, in effect saying, 
that spirituality gives life warmth and colour and energy. In other words, it is, in itself, life-giving: "I think without being spiritual life would be very cold. I think it would be very black and white...I think it would take the sparkle out of life."

\subsubsection{Spirituality Provides Guidance and Protection}

The quotes illustrating the theme of guidance and protection are very powerful and really provide a snapshot into how their spiritual beliefs provide the participants with a strong feeling of being supported and protected, rather than feeling alone and helpless. RN's excerpt projects an image of spirituality as a shield in the strife: "Hm [sic], I suppose it surrounds you. Like a coat, like something for going out in the cold that gives you protection, that's around you, that you evoke." (RN).

KS's quote is quite striking: "It's just my total crutch, without God I am nothing, I can say that. That's just the bottom line." (KS).

KS' spirituality helped her in increasing her self-awareness and accepting the fact that humans do not have control over everything that happens in life. She had learned that trying to solve and fix everything and everybody in her life on her own all the time had often led to setting herself up for failure. This, in turn, led her into depression. She had also suffered from various addictions and contemplated suicide on one occasion. Through trusting in God she came to accept that not everything is her responsibility and she felt tremendous relief. She tellingly compared the time before she had this realisation ("When I ran on my own self-will") to the time when she learned to have faith, as: "Between insanity and sanity."

MR, who declared that spirituality is part of her life now and that she would not want to do without it, simply and powerfully put it like this: "It's a great source of help to me, I don't think I could survive without it." (MR).

\subsubsection{Coping through Creative Expression}

The multidimensional construct of creativity emerged as a mode of self-expression and was another constituent theme to the super-ordinate theme of "Transformation". As such, it contained the sub-themes of focus, perspective, sharing and connecting, purpose, self-esteem, joy, and self-awareness as well as that of alleviating anxiety. In addition, the participants perceived creativity to be an aspect of spirituality. Creativity, like spirituality, is a very subjective construct, meaning different things to different people.

RN captures the idea of creative potential in her quote and links it directly into the idea of opportunity. As a very creative person herself, she considers herself lucky to be able to use her creativity in her daily life: "I think we are all capable of so much creativity. It's just if you are lucky to find the expression." (RN).

$\mathrm{TC}$, one of the two participants who was not actively creative, also made reference to the creative potential, as the following quote demonstrates. He demonstrated his interest in poetry with an ad-hoc recital of a poem. The impression during the interview was that TC had indeed the potential and interest to be creative but due to lack of nurture and opportunity had not found a way of expressing it: "I would acknowledge that yes, surely, there's a creative person in there, that just never took time or the energy or was too lazy to try the things." 
Creative self-expression as an inner need is portrayed very well in PT's quote: "Someone who needs to express themselves through drawing or writing." (PT).

TC, who was not actively creative and was not given the opportunity for creativity in his earlier years, nevertheless displayed not only a propensity for creativity when he recited a poem ad hoc during the interview, but also a profound understanding of the concept of creativity which the following quotation demonstrates. He describes a creative person as someone who has a different perspective on life; a sense of awe and wonder; someone who not only sees things differently but is able to share what he perceives with others through creative expression.

A person who is able to see all these aspects of beauty and truth and goes beyond that and is able to express them in a way that evokes a response from his public, his fellow man. (TC).

KS gives a good example of creative coping in action. When she feels unwell, she resorts to creative writing (poetry) in order to express her feelings. By writing about her feelings she is dealing with them and is able to manage them. This, in turn, helps her in her process of recovery from illness:

Yes. In times of illness I would, I use my writing as well to just, to express my feelings today, to get my feelings...onto paper; to take my emotions and get them out of my system and by removing the emotions from my being I am opening myself to new avenues of recovery. (KS).

\subsubsection{Creativity is an Aspect of Spirituality}

The participants who described themselves as both creative and spiritual, understood creativity as an aspect of spirituality. At the end of the interview, when asked whether she would like to add anything, MR said she felt that creativity and spirituality are mutually associated and that this combination provides a good coping strategy. "I feel both things kind of go hand in hand because one thing has come out of the other and they do, they link in. They link in in helping, both things help in different ways." (MR).

$\mathrm{RN}$, when asked where she believes her creativity comes from, made a clear and direct link from spirituality to creativity, thereby supporting the idea of creativity being an aspect of spirituality:"[My creativity comes] From the ultimate spiritual, spirituality within me, the God within me. Or the spirit within me." (RN).

$\mathrm{RN}$ felt very strongly about this association and made repeated reference to it throughout the interview. In her view, both spirituality and creativity are rooted in the spirit. "So, I would believe that it's that elusive spirit that brings together the two, you know, and where the two can meet there and that they speak the same language." (RN).

$\mathrm{JB}$, when asked whether he could imagine without creativity, said that whilst he would find it very hard not to be able to pursue ideas, he would find it harder still to live without spirituality. To him, spirituality was a higher order concept and expressed itself in his art. This, of course is a strong demonstration of the proposed association between creativity and spirituality, and more specifically, of the idea that creativity is, in fact, an aspect of spirituality. 
I would still say that a spiritual outlook in life is still far more important than the creativity, as long as I still have the spiritual side, because it would be on the higher level, so I wouldn't put creativity on the top, I would still put it secondary to the spiritual things in the world, so I would say that in that sense my spirituality would actually flow through my art without a doubt. (JB).

KS said she could not imagine life without creativity, believing it to be a gift from God who was the central figure in her spirituality. She very clearly sees creativity as potential which serves the purpose of self-actualisation and personal growth and development. Again, the creativity - spirituality link is very powerfully expressed here. KS, like JB, also sees creativity as an aspect of spirituality:

I could not imagine life without being creative because to me creativity, in whatever form it comes, is a gift from God, and as a gift from God, it has been given to us to broaden our being, you know, to bring us out and help us to flower. You know, we are a seed and we are growing and our creativity has been given to us to enable us to blossom. (KS).

KS gave a very good description of transformative coping in action. She describes how she resorts to her creativity on a daily basis. In fact she says she needs to do that. She then explains how she combines her creative writing with mediation and how she puts the results of her reflections to use all day in order to deal with negative emotions or difficult situations.

I need to use my creativity every day of my life. I write in the morning, I pray, I meditate, I meditate on a word or a line or a maybe just a thought that I have. If the word's love, I write down you know, what love means to me. And then I just meditate for a period of time. I try to carry that word with me all through my day and I envisage whatever the line, whatever anger, it could be anger, and if the word's anger, then how I handle that through the day is that anger is not from the God of my understanding. (KS).

\subsubsection{Creativity Alleviates Anxiety}

A number of examples for creativity providing relief from anxiety were given by the participants, such as the following excerpt from PT's interview. It illustrates how she responds to tension and anxiety by resorting to her creativity, which makes her feel calmer.

Yes, the more sort of nervy and edgy I would feel, the more creative I would be and the more I would sit down and do some writing, some painting...It sort of grounds me a bit. Being calmer. (PT).

SC who had suffered badly with fear earlier in his life, wrote poetry himself. He believed that reading others' poetry also helped to alleviate his anxiety: "Bit of poetry how you feel better, you know. I think that's mostly for beating fear." (SC).

$\mathrm{JB}$, who had suffered severe anxiety in his younger years, describes his creative process as therapeutically beneficial to him. It provides him with a safe space he can withdraw to when faced with difficulty and where the repetitive nature of his creative work calms him and provides him with stability:

You go into your own world whenever you are working on your art, but no matter what happens on the outside world, you'd still be contained in this cocoon, in your own little 
head space while you're making your art, whether its there's instability in your domestic life, you still go into this little place...It is a repetitive kind of process so in that sense it is quite therapeutic because it gives you a grounding and stability. (JB).

LM referred to anxiety and fear frequently during her interview and explained that the act of painting keeps her anxieties at bay. Her creativity is of such significance to her that she compares it to breathing. Even as she said this her voice and demeanour had a tormented quality.

I am a painter. I paint every day. I work full time as a painter. When I stop I get absolutely full of anxiety. You've no idea. It's like breathing to me. (LM).

The phrase "when it's taken away from me" suggests a belief in external locus of control which would explain LM's intense and enduring feelings of anxiety. In the following quote LM also refers to difficult things having happened in her life. The interview did not shed any further light on this, however, as this remark was made alongside an implicit reference to external locus of control, and anxiety in the absence of creative expression, it stands to reason that the three things are somehow associated.

Well, I know that when it's taken away from me I am full of anxieties, you know, so, it's the absence that creates a lot of anxieties. Obviously, there is other things in my life that have happened, that are... and part of that would be difficult. (LM).

The next quote is more explicit in as much as LM explains that her painting serves as a healing process. Her description is reminiscent of someone putting ointment onto a wound. Again, the mention of anxieties, fears and "things that happened":

For instance the material I use, I tend to use layer upon layer so I think I probably cover up a lot. I cover up and cover up and cover up. In a sense there is this therapeutic healing and somehow covering up the hurt and dealing with anxieties, fears and things that happened, by the actual act of painting. (LM).

\subsubsection{Creativity Facilitates Sharing and Connecting}

Sharing with others and thus being able to connect with them was another sub-theme of creative expression. LM explains this in her quote; which illustrates that when it comes to the product of a creative expression; it is equally satisfactory for the spectator or reader; etc. to understand and connect with what the creator was trying to express; as the expression of it is for the creator.

But you can share, I mean even being able to read a poem and get it. You know, when you get something, I mean that is being creative, because that's our combined...as human beings, this is what we share, this ability, this is what raises us above animals. (LM).

$\mathrm{HN}$, who was himself not actively creative and did not appear to have been given the opportunity to get creative in his early days, was nevertheless very appreciative of creativity: "I admire people who are creative, you know." He also linked creativity with the sharing of emotions between the creator and the spectator:

See human beings really have emotion, right, and like you could hear a piece of music that maybe is so beautiful that it makes you cry, you know. So, you need creativity; or people 
like to go and look at art and they can get lost in a piece of art and they can study it for ages and ages. (HN).

The quotations in this category have demonstrated that creativity fosters a positive connection between the creator and the spectator through the sharing of human emotions. KS gives another insight into the creator's perspective of this process. She describes how she derives satisfaction (self-esteem!) from the act of creating something, and joy about being able to share what she enjoys with other. "....and to feel good about the work you have done and then, in turn, be able to pass your experience of something very beautiful onto someone else.” (KS).

\subsubsection{Creativity Provides Focus}

Coming back to the subjectivity of creative expression, the analysis has made it clear, that different interviewees derived different benefits from creative expression. Focus, for example is a benefit which was very important to MR. She and her sister started being creative in order to deal with their feelings of grief. They refurbished caravans as a way of coping with the difficult time after MR's nephew died. This activity allowed them to mentally focus on something productive which they perceived as enjoyable and rewarding: "I didn't realise it was creativity. Just thought it was something to focus on and something to put a different light on things." (MR).

In doing so, they were able to distance themselves from the negative emotions, so they did not become overwhelming but get a bit dispersed and could be managed a little easier: "It definitely was a different focus, to get away from the sadness." (MR).

In addition, MR and her sister took to flower arranging in response to their grief. Again, it is a powerful illustration of how creative expression can help to transform negative emotions into positive ones. The flower arranging provided them not only with focus but with a good deal of joy and satisfaction, thereby counteracting the intense feelings of sadness. "...the flower arranging started after Michael's death...me and my sister together and I think it helped us to focus on something else.” (MR).

\subsubsection{Creativity Gives Joy}

The positive emotion of joy was another sub-theme of creative expression, which, in LM's case, she described as deriving from the excitement that her creativity provided and the opportunity of learning something new. "Yes, an excitement, an interest in discovery, in learning something." (LM).

LO described how he used to sit in a park, or on the underground in London and write poetry. He too, felt that writing poetry gave him joy as it made him feel better about himself and increased his self-esteem. This joyfulness was almost palpable in his voice and facial expression at this point in the interview. "Sitting there and writing a poem and coming away feeling happier. I mean it's an achievement." (LO).

MR described that sense of joy, too, which she felt she received as a result of her interior design and flower arranging which she started during her grieving process. "Well, I think it definitely puts the focus on something else, not even yourself and what you are going through and brings more joy into your life, definitely." (MR). 
JB explained how his creative activity brings him joy. The excitement of a new idea forming in his mind and the anticipation of translating it into a finished product are themes in his quotation:

But certainly, it releases endorphins, so I suppose in a sense there is something that happens creatively on an idea and you get that feel-good factor and you are making the idea sort of alive in your head as you are constructing. (JB).

When RN was asked whether she remembered an instance where her creativity has helped her overcome a problem, she explains how, when she feels unhappy, singing or listening to singing lifts her emotions and makes her feel happier. She emphasises the power of music to elevate one's spirit:

Yes, well, singing certainly does. You know, dark thoughts are lessened really. So, yes I would if I am feeling down I'd sing a piece of chant or go over to the church and listen to it. Ehm [sic], so yes I think it's really when your emotions are affected really that you can dispel a certain darkness, you know and there's something very healing in singing or listening to it. Does not have to be singing yourself, you know. That's why music is so powerful; it just has that power to take you onto another level. (RN).

\subsubsection{Creativity Provides Meaning}

As with spirituality, meaning was implicated strongly within the participants' answers as to their creativity. KS, who believes that creativity is a gift from God, gives a beautiful account of why exactly she perceives creativity as meaningful. She said:

It has been given to us to use to broaden our being, you know, to bring us out and help us to flower. You know, we are a seed and we are growing and our creativity has been given to us to enable us to blossom. (KS).

The view of creativity being inherent in human nature is incorporated into her quote, along with the idea of self-actualisation [24]. In other words, KS believes that the meaning of creativity is to enable people to be the best they can be.

The participants shared the view that life without creativity would be less meaningful. In ML's case, the immense significance that creativity has in her life, came across strongly in the interview where she talked about how it is one of her worst nightmares to be in a situation where she would not be able to pursue her art. The anxiety and horror of even just imagining such circumstances were obvious in her voice and facial expression during the discussion of this point: "It's having nothing to work with creatively, you know. When I think of that worst scenario, I always think 'What could I do?'” (LM).

JB thought along the same lines, although not with the same urgency by far. He believed that life would be very dull without being able to express himself creatively. However, I might mention at this point again, that he was also very spiritual and stated that his spirituality was more important to him than his creativity. "No, it certainly wouldn't be very exciting, you know, to have ideas and not be able to pursue them." (JB).

In contrast, LM saw herself as not spiritual (although she demonstrated that she believed in and observed some important spiritual values, e.g., respect for oneself, others and nature) and did, therefore, not resort to spirituality, but resorted to creativity as a much valued coping strategy. 


\subsubsection{Creativity Provides Self-Esteem}

Self-esteem emerged as another subtheme to creative expression. It describes feelings of self-worth and pride resulting from having created something unique, as KS explains: "I love writing and to be able to take something and turn it into your own interpretation and to feel good about the work you have done." (KS).

SC, who started writing poetry after he came out of hospital 20 years ago following a mental breakdown, quietly, but proudly said: "I have some 68 published." (SC).

And LO captures the effects of self-esteem when he suggests that looking back on his creative achievements made him feel good about himself when he was going through more difficult times: "Well, I found if you are having a difficult time you look back on your achievements, and your achievements can be creative." (LO).

\section{Discussion}

The aim of the present study was to establish whether, and if so, to what extent individuals use their creativity as well as their spirituality in coping throughout their lifespan, how they are helped by resorting to them, and how important they are to them. The study critically examined the TTC and associated TCM-R from a qualitative perspective. Ten interviews were conducted among Northern Irish and Irish artists, contemplative prayer group members, and mental health service users. Data were analysed using IPA.

The participants provided an abundance of rich and complex data and have been very forthcoming not only in their answers to the interview questions but also in elaborations beyond that, thus providing an intimate picture of what the application of both creativity and spirituality meant for them and how important it was in their lives.

Eight out of ten participants saw themselves as creative and believed that creativity was in their nature (JB, LM, RN, LO, SC, PT, KS, MR). A further participant, although not actively creative, said he passively enjoyed others' creativity by watching films and listening to music in order to relax (HN). Another participant did not report resorting to creativity as a coping strategy either, yet seemed very familiar with poetry and proceeded to recite a poem ad-hoc during the interview (TC).

Out of the eight actively creative interviewees, six believed that their creativity had been nurtured in childhood (JB, LM, RN, LO, KS, MR), two did not (SC, PT). Four respondents have resorted to creativity in order to cope with illness (JB, LM, RN, MR). All eight have resorted to creativity in order to cope with stressful situations and with daily hassles; seven (all but PT) had resorted to it in difficult times and all eight had employed creativity to overcome a problem. None of them could imagine their life without being creative as they saw it as an intrinsic part of their lives. "It's a great source of help to me. I don't think I could survive without it." (MR)

Equally, most respondents (JB, RN, LO, SC, KS, TC, MR) saw themselves as spiritual and believed that spirituality was in their nature. Only three of them were also religious (KS, TC, MR), with the remaining four describing themselves as spiritual only (JB, RN, LO, SC). Three participants (LM, HN, PT) described themselves as not spiritual. Two of them (LM, PT) were creative, however. HN saw himself as neither actively creative nor spiritual. The distinction of spirituality from religion was an 
important one for four of the participants (JB, RN, LO, and SC). Out of the seven, six believed that their spirituality had been nurtured in childhood (all but JB). Four respondents had resorted to spirituality in order to cope with illness (JB, LO, SC, KC). All seven have resorted to spirituality in order to cope with stressful situations, daily hassles, and difficult times; and six had employed spirituality to overcome a problem (all but TC). None of the seven could imagine their life without being spiritual as they saw it as an intrinsic part of their lives, and, indeed, as part of their identity. "It's my essence, I think, yeah." (RN). "I would say that definitely God is a very central part of my life." (MR).

Overall, these findings indicate that both creativity and spirituality were important aspects in the participants' lives. Most of the interviewees applied either creativity or spirituality as a coping strategy on a regular basis in order to cope with stressful events and situations, with six out of ten applying a combination of both, effectively employing transformative coping. It is interesting to note that these six participants were equally distributed across the three groups, i.e., they were two artists (JB and $\mathrm{RN}$ ), two mental health group members (SC and LO), and two prayer group members (KS and MR). In line with the literature findings (e.g., $[4,5,8,37,38]$ ) creativity was found to be an aspect of spirituality. As JB put it: "My spirituality flows through my art, without a doubt."

The super-ordinate theme was identified as "Positive transformation" which contained the main theme of "Coping through creative expression", with the subthemes of "creativity is an aspect of spirituality", "creativity alleviates anxiety", "creativity facilitates sharing \& connecting", "creativity provides focus", "creativity gives joy", "creativity provides meaning", and "creativity provides self-esteem"; and the main theme of "Coping through a spiritual attitude/way of life", with the subthemes of "Spirituality is distinct from religion", "spirituality fosters connectedness to God, self, and others", "Spirituality helps combat depression and addiction", "spirituality gives perspective", "spirituality gives hope", "spirituality provides meaning", and "spirituality provides guidance and protection". "Connecting with others" and "meaning" have emerged as shared benefits of creativity and spirituality (see Figure 2).

There were clear individual differences with regard to theme endorsement. In other words, certain themes were of particular importance to certain individuals. For example, MR's main benefits were joy and focus; TC's and JB's core benefit transpired as perspective; LM's and PT's main benefit was reduced anxiety; to LO and MR hope was an important theme, and for KS guidance had the greatest significance. This shows that, within the umbrella of a shared and collective understanding of the benefits of creativity and spirituality in coping, the participants attained personal meaning and its resulting benefits from transformative coping.

The TCM-R (see [6] for the original version) is supported by the findings of this study. In line with the model's premise, the theme of "creativity is an aspect of spirituality" emerged from the participant-driven analysis. Rather than focusing on their problems, the majority of the participants had chosen to enhance their psycho-spiritual wellbeing actively through the sustained application of a combination of creativity and spirituality and felt that this was a very important and integral part of their lives. They believed that they would not cope as well without it and could not imagine their lives without it (see Table 1). Transformation, a benefit derived from both creativity and spirituality $[39,40]$ can be said to be of crucial importance to the participants. The replacing of 
negative emotions with positive ones and the consequent perceived improvement in mental health and well-being is central to this positive and proactive approach to coping in the interviewees' lives.

The findings indicated that the participants perceived creativity and spirituality to be associated and, more specifically, believed creativity to be an aspect of spirituality, providing support for the proposed link between creativity and spirituality (see [1-3,11,13,14,40,41]).

In support of the TCM-R the combined application of creativity and spirituality facilitated emotional expression and enabled the interviewees to increase their self-awareness, personal resources and growth. In line with Moritz, Kelly, Angen, Quan, Toews, and Rickhi's [28] findings, perspective was a shared benefit. The benefits of creative expression as a positive focus and perceiving God as a friend were reported as meaningful outcomes. Thus, the active and conscious application of creativity and spirituality combined in an effort to essentially manage emotions was shown to be of immense importance to six out of ten participants who felt that it was an integral part of their lives and that they would not cope as well without it. It can be said that the commitment to resort to the associated coping resources of creativity and spirituality constitutes transformative coping and is a consciously chosen way of life. As such the study supported previous research which reported on the mental health benefits of creativity (e.g., [41,42]) and spirituality (e.g., [43,44]) respectively, while adding a new dimension, namely that of the association between spirituality and creativity and their role in coping.

A somewhat unexpected finding was the extent to which they were united in having experienced adverse life events, and ongoing stressful situations in their lives and, in some cases, trauma. Six participants reported traumatic or stressful experiences, with a further two alluding to difficult situations. For example, loss of loved ones, loss of employment, loneliness, conflict (including the Northern Ireland "troubles") and separation. The traumas or stressful situations appeared to be directly implicated in the mental health history in each life story. Only three out of ten participants reported physical illness (such as food allergies, hernia, obesity, and a suspected heart attack). These findings lend support to Lazarus [15] who posits that hardship is inherent in human life, creating trauma and leading to negative emotions, resulting in psychological stress. Individuals who are deficient in coping resources are particularly vulnerable to suffer from mental ill-health. Ineffective coping with stress as a prelude to mental ill-health is emphasised by the World Health Organization [44]. The results are also in line with Holmes and Rahe's [45] observations that major changes in life (e.g., health, employment, moving, finances) precede the development of disease.

The majority of the interviewees had suffered some form of mental ill-health (see Table 1), albeit not all had been formally diagnosed and treated. Seven out of ten participants had been diagnosed with and treated for a mental illness in the past, with a further two respondents repeatedly referring to anxiety throughout the interview. In addition, two interviewees had contemplated suicide in the past.

Contrary to intentions, nine out of ten interviewees were Catholic and one was non-denominational. Further studies with a wider spread of religious denominations, in order to establish potential differences in transformative coping, are recommended. The findings demonstrated that all participants believed their creativity and spirituality were a result of both nature and nurture. This can be said to support a systemic view of the concepts (see e.g., [46]), placing them in a personal, cultural and historical context. It would be interesting and worthwhile to further qualitatively investigate the extent to which nurture and culture have a direct impact on creative and spiritual coping. 


\section{Practical Applications}

Pending further studies testing the TTC and TCM-R with diverse populations, it is hoped that the TCM-R could be incorporated into therapy, mental health promotion and programs for recovery from mental illness and addiction, in order to enable individuals to resort to their inherent positive resources of creativity and spirituality by way of transformative coping, throughout the lifespan. Individuals may benefit greatly from connecting with their innate spirituality and creativity; from arriving at a mature understanding of the concepts, and from consequently harnessing their combined and mutually nurturing benefits. As a result they would have a more powerful and effective tool to transform negative emotions (e.g., anger, sadness, despair, hate, disappointment, guilt, fear, etc.) into positive ones (e.g., acceptance, understanding, forgiveness, hope, meaning, joy, love, optimism, self-esteem, etc.), in line with the conceptual framework for transformative coping (TCM-R). It may be that they would be able to appraise future traumas or stressful events from a position of improved inner strength and decreased vulnerability. Consequently, they may be more resilient and less likely to suffer from mental ill-health.

\section{Conclusions}

The rich data collated within this study have extended current theoretical knowledge in the areas of coping, creativity, spirituality and mental health. They substantiate and give meaning to the lived experience of transformative coping. The findings showed that there are differences in the extent to which individuals apply transformative coping. Therefore, the integration of creative and spiritual resources into client-centred counselling and psychotherapy is proposed, offering clients a positive, respectful and individualistic choice, enabling them to address coping difficulties throughout the lifespan. In order to aid the prevention of mental-ill health, promote mental health and build people's strengths and capacities, the principles of the TCM-R could be taught in educational settings and promoted by health centres, mental health charities, practitioners in primary care, and other health professionals in order to reach the wider population. To facilitate this, practitioners could be trained in how to apply the TTC and TCM-R in practice in order to be able to offer their clients a personalised coping strategy.

\section{Author Contributions}

Dr Dagmar A. S. Corry designed and performed the research, analysed the data, and wrote the paper. Dr Tracey assisted with the interpretation of results. Professor Christopher Alan Lewis helped to write the paper. All authors read and approved the final manuscript.

\section{Conflicts of Interest}

The authors declare no conflict of interest.

\section{References}

1. Wassily Kandinsky. Concerning the Spiritual in Art. Mineola: Courier Dover Publications, 2012. 
2. Leo Tolstoy. What is Art? Translated by Richard Pevear and Larissa Volokhonsky. London: Penguin Books Ltd., 1995.

3. Earle J. Coleman. Creativity and Spirituality: Bonds between Art and Religion. Albany: SUNY Press, 1998.

4. Christopher G. Edwards. "Creative writing as a spiritual practice: Two paths." In Creativity, Spirituality and Transcendence: Paths to Integrity and Wisdom in the Mature Self. Edited by Melvin E. Miller and Susanne R. Cook-Greuter. Stamford: Ablex Publishing Corporation, 2000, pp. 3-23.

5. Kelley Raab Mayo. Creativity, Spirituality, and Mental Health: Exploring Connections. Farnham: Ashgate Publishing, Ltd., 2013.

6. Dagmar A.S. Corry, Christopher A. Lewis, and John Mallett. "Harnessing the mental health benefits of the creativity-Spirituality construct: Introducing the Theory of Transformative Coping." Journal of Spirituality in Mental Health 16 (2014): 89-110.

7. Anthony D. Ong, Lisa M. Edwards, and Cindy S. Bergeman. "Hope as a source of resilience in later adulthood." Personality and Individual Differences 41 (2006): 1263-73.

8. Stanley Jacobs. "Creativity, science, and spirituality." Perspectives, 15 September 1996. Available online: http://metapsychology.mentalhelp.net/poc/view_doc.php?type=de\&id=295 (accessed on 6 May 2009).

9. Peter Bray. "A broader framework for exploring the influence of spiritual experience in the wake of stressful life events: Examining connections between posttraumatic growth and psycho-spiritual transformation." Mental Health, Religion \& Culture 13 (2010): 293-308.

10. John E. Roberts, Anne M. Shapiro, and Stephanie A. Gamble. "Level and perceived stability of self-esteem prospectively predict depressive symptoms during psychoeducational group treatment." British Journal of Clinical Psychology 38 (1999): 425-29.

11. Melvin E. Miller, and Susanne R. Cook-Greuter. Creativity, Spirituality, and Transcendence: Paths to Integrity and Wisdom in the Mature Self. Edited by Melvin E. Miller and Susanne R. Cook-Greuter. Santa Barbara: Greenwood Publishing Group, 2000.

12. Frances Reynolds, Kee H. Lim, and Sarah Prior. "Images of resistance: A qualitative enquiry into the meanings of personal artwork for women living with cancer." Creativity Research Journal 20 (2008): 211-20.

13. Kenneth I. Pargament. Spiritually Integrated Psychotherapy: Understanding and Addressing the Sacred. New York: Guilford Press, 2011.

14. Dana Zohar, and Ian Marshall. Spiritual Intelligence: The Ultimate Intelligence. London: Bloomsbury, 2000.

15. Richard S. Lazarus. "Hope: An emotion and a vital coping resource against despair." Social Research 66 (1999): 653-78.

16. Barbara L. Fredrickson. "The broaden-and-build theory of positive emotions." Philosophical Transactions-Royal Society of London Series B Biological Sciences 359 (2004): 1367-78.

17. Richard S. Lazarus, and Susan Folkman. Stress, Appraisal, and Coping. Berlin and Heidelberg: Springer Publishing Company, 1984. 
18. Michelle Palmer, Michael Larkin, Richard de Visser, and Gráinne Fadden. "Developing an interpretative phenomenological approach to focus group data." Qualitative Research in Psychology 7 (2010): 99-121.

19. Richard C. Snyder. "Hope theory: Rainbows in the mind." Psychological Inquiry 13 (2002): 249-75.

20. Judith Lee. "Melancholy, the muse and mental health promotion-An analysis of the complex relationship between mood disorder and creativity, developing a specific model of mental health promotion: Six key themes." International Journal of Mental Health Promotion 9 (2007): 4-16.

21. Michael F. Valle, E. Scott Huebner, and Shannon M. Suldo. "An analysis of hope as a psychological strength.” Journal of School Psychology 44 (2006): 393-406.

22. Vanessa Juth, Joshua M. Smyth, and Alecia M. Santuzzi. "How do you feel? Self-esteem predicts affect, stress, social interaction, and symptom severity during daily life in patients with chronic illness." Journal of Health Psychology 13 (2008): 884-94.

23. Joaquim J.F. Soares, and Giorgio Grossi. "The relationship between levels of self-esteem, clinical variables, anxiety/depression and coping among patients with musculoskeletal pain." Scandinavian Journal of Occupational Therapy 7 (2000): 87-95.

24. Abraham Maslow. "The creative attitude." In Explorations in Creativity. Edited by Ross L. Mooney and Taher A. Razik. New York: Harper \& Row, 1967, pp. 43-57.

25. Viktor E. Frankl. Man's Search for Meaning. Boston: Beacon Press, 1959.

26. Mindy Greenstein, and William Breitbart. "Cancer and the experience of meaning: A group psychotherapy program for people with cancer." American Journal of Psychotherapy 54 (2000): 486-500.

27. Man Yee Ho, Fanny M. Cheung, and Shu Fai Cheung. "The role of meaning in life and optimism in promoting well-being." Personality and Individual Differences 48 (2010): 658-63.

28. Christopher Madden, and Taryn Bloom. "Creativity, health and arts advocacy." International Journal of Cultural Policy 10 (2004): 133-56.

29. Diarmuid Ó’Murchú. Reclaiming Spirituality: A New Spiritual Framework for Today's World. New York: The Crossroad Publishing Co., 1998.

30. Michael F. Steger, Shigehiro Oishi, and Todd B. Kashdan. "Meaning in life across the life span: Levels and correlates of meaning in life from emerging adulthood to older adulthood." The Journal of Positive Psychology 4 (2009): 43-52.

31. David J. Wilde, and Craig D. Murray. "The evolving self: Finding meaning in near-death experiences using Interpretative Phenomenological Analysis." Mental Health, Religion \& Culture 12 (2009): 223-39.

32. Sheryl Zika, and Kerry Chamberlain. "On the relation between meaning in life and psychological well-being.” British Journal of Psychology 83 (1992): 133-45.

33. Jonathan A. Smith. "Beyond the divide between cognition and discourse: Using interpretative phenomenological analysis in health psychology." Psychology and Health 11 (1996): 261-71.

34. Jonathan A. Smith, and Mike Osborn. "Interpretative phenomenological analysis." In Qualitative Psychology: A Practical Guide to Research Methods. Edited by Jonathan A. Smith. Thousand Oaks: Sage Publications Ltd., 2003, pp. 51-80. 
35. Jonathan A. Smith, Maria Jarman, and Mike Osborn. "Doing interpretative phenomenological analysis.” In Qualitative Health Psychology. Edited by Michael Murray and Kerry Chamberlain. London: Sage Publications Ltd. 1999, pp. 218-39.

36. QSR International. “About QSR: Our History.” Available online: http://www.qsrinternational.com/ about-qsr_history.aspx (accessed on 2 April 2011).

37. Mahmoud Awara, and Christopher Fasey. "Is spirituality worth exploring in psychiatric out-patient clinics?" Journal of Mental Health 17 (2008): 183-91.

38. Co-Shi C. Chao, Chen Ching-Huey, and Yen Miaofen. "The essence of spirituality of terminally ill patients." Journal of Nursing Research 10 (2002): 237-45.

39. Deirdre Heenan. "Art as therapy: An effective way of promoting positive mental health?" Disability \& Society 21 (2006): 179-91.

40. Sabine Moritz, Mary Kelly, Maureen Angen, Hude Quan, John Toews, and Badri Rickhi. “The impact of a home-based spirituality teaching programme: Qualitative exploration of participants' experiences." Spirituality and Health International 8 (2007): 192-205.

41. Shaun McNiff. Art Heals. Boston: Shambhala Publications, 2004.

42. Michal M. Mann, Clemens M.H. Hosman, Herman P. Schaalma, and Nanne K. de Vries. "Self-esteem in a broad-spectrum approach for mental health promotion." Health Education Research 19 (2004): 357-72.

43. Sean Fleming, and David S. Evans. "The concept of spirituality: Its role within health promotion practice in the Republic of Ireland." Spirituality and Health International 9 (2008): 79-89.

44. World Health Organization. The World Health Report 2001. Mental Health: New Understanding, New Hope. Geneva: World Health Organization, 2001.

45. Thomas H. Holmes, and Richard H. Rahe. "The Social Readjustment Rating Scale." Journal of Psychosomatic Research 11 (1967): 213-18.

46. Mihaly Csikszentmihalyi, and Judith LeFevre. "Optimal experience in work and leisure.” Journal of Personality and Social Psychology 56 (1989): 815-22.

(C) 2015 by the authors; licensee MDPI, Basel, Switzerland. This article is an open access article distributed under the terms and conditions of the Creative Commons Attribution license (http://creativecommons.org/licenses/by/4.0/). 